\title{
Jeremy Bentham and Equity: the Court of Chancery, Lord Eldon, and the Dispatch Court Plan
}

\author{
CHRIS RILEY
}

\begin{abstract}
In 1929 Sir William Holdsworth argued that Jeremy Bentham wrote 'the best criticism' of Lord Mansfield's attempts to 'fuse' law and equity that has ever been made. As the present article will show, Bentham was in fact in favour of a form of 'fusion' that consisted of the abolition of the procedural distinction between law and equity, the incorporation of the subject-matters ordinarily handled by equity courts into his Civil Code, and the inclusion of formal mechanisms to provide relief and to amend the law in his ideal constitution. In the immediate term, Bentham devised a series of 'equity dispatch courts' that would employ a summary method of procedure in order to clear the large backlog of Lord Eldon's court of chancery. While he claimed that this project would be experimental and temporary, he often portrayed it as an avenue through which to instigate radical reform, and to eliminate entirely the need for separate systems of law and equity. However, it will be concluded that, with the exception of Henry Bickersteth, Bentham's writings on equity gained little influence in the decades preceding the Supreme Court of Judicature Acts (1873-5), and achieved only a small circulation.
\end{abstract}

\section{Keywords: Jeremy Bentham, Lord Eldon, court of chancery, equity}

\section{I.INTRODUCTION}

As Postema notes, Jeremy Bentham's 'hatred' of the English common law system is 'legendary', ${ }^{1}$ and what J.H. Burns calls his 'lifetime's dialectic' with the common law champion Sir William Blackstone is no less well known. ${ }^{2}$ However, with a few exceptions, Bentham's keen interest in English equity in general, and in the court of chancery in particular, have

${ }^{1}$ G.J. Postema, Bentham and the Common Law Tradition, Oxford, 1986, 192.

2 J.H. Burns, 'Bentham and Blackstone: A Lifetime's Dialectic', 1 Utilitas (1989), 22. 
passed by without sustained attention. ${ }^{3}$ Furthermore, according to John Bowring, the man whom Bentham viewed as the 'mightiest and most mischievous of all the opponents of law reform'-and whom he 'hated as much as it was possible [in] his benevolent nature to hate'was not in fact Blackstone, but John Scott, first earl of Eldon, who served as lord chancellor in $1801-6$ and again in 1807-27. ${ }^{4}$

A particularly rare and striking reference to Bentham's views on equity appeared in the first published edition of $A$ Comment on the Commentaries (1828), edited by Charles Everett. ${ }^{5}$ In his editorial introduction, Everett claimed to have identified a particular 'topical' reference to

${ }^{3}$ The most detailed treatment is to be found in Postema, Bentham and the Common Law Tradition, 413-421. See also E. Halévy, The Growth of Philosophic Radicalism, trans. M. Morris, London, 1928, 382; P. Schofield, Utility and Democracy: The Political Thought of Jeremy Bentham, Oxford, 2006, 324-326; M. Sokol, Bentham, Law and Marriage: A Utilitarian Code of Law in Historical Contexts, London, 2011, 68-70; J.R. Dinwiddy, Bentham: Selected Writings of John Dinwiddy, W. Twining ed., Stanford, 2004, 158; W.S. Holdsworth, A History of English Law, 17 vols., 2nd edn., London, 1903-38, i. 635 [hereafter HEL]; K. Blake, Pleasures of Benthamism: Victorian Literature, Utility, Political Economy, Oxford, 2009, 8-10; C.M. Atkinson, Jeremy Bentham: His Life and Work, London, 1905, 128, 193; J.E. Crimmins, Utilitarian Philosophy and Politics: Bentham's Later Years, London and New York, 2011, 170, 177.

${ }^{4}$ The Works of Jeremy Bentham, Published under the Superintendence of His Literary Executor John Bowring, 11 vols., Edinburgh, 1838-43, x. 180 [hereafter Bowring]. ${ }^{5}$ A Comment on the Commentaries: a Criticism of William Blackstone's Commentaries on the Laws of England, C.W. Everett ed., Oxford, 1928, 24. The critical edition of the text is 'A Comment on the Commentaries and A Fragment on Government', The Collected Works of Jeremy Bentham, J.H. Burns \& H.L.A. Hart eds., Oxford, 1977 [hereafter $(C W)$ ]. Unless otherwise specified, this is the edition used throughout. 
William Murray, first earl of Mansfield. ${ }^{6}$ Everett referred to the case of Atkins v Hill $(1775)^{7}$ but provided a quotation from Hawkes v Saunders (1782), ${ }^{8}$ which was decided long after Bentham ceased working on A Comment on the Commentaries. As Everett noted, in these two cases Mansfield attempted to overturn the common law doctrine of consideration by replacing it with a much broader equitable one. ${ }^{9}$ Mansfield asserted that 'wherever a defendant is under a moral obligation, or is liable in conscience and equity' to pay a given sum, such a moral obligation ought to act as a 'sufficient consideration' in contract. ${ }^{10}$ In an article entitled 'Blackstone's Treatment of Equity' (1929), Sir William Holdsworth agreed with Everett that Bentham had in mind Mansfield's attempt to 'fuse' law and equity within the reference in question. ${ }^{11}$ In so doing, Holdsworth argued that Bentham had written 'the best criticism' of this attempt that 'has ever been made'. ${ }^{12}$ The relevant passage from $A$ Comment on the Commentaries is worth quoting at length.

Should there be a Judge who enlightened by genius, stimulated by honest zeal to

${ }^{6}$ A Comment on the Commentaries, Everett ed., 24. Citing Holdsworth, HEL, viii. 2629.

${ }^{7}$ (1775) 1 Cowper 284; 98 E.R. 1088.

8 (1782) 1 Cowper 289; 98 E.R. 1091.

${ }^{9}$ A Comment on the Commentaries, Everett ed., 24. This attempt ultimately failed. See W.S. Holdsworth, 'Lord Mansfield', 53 Law Quarterly Review (1937), 221, 225; W. Swain, The Law of Contract: 1670-1870, Cambridge, 2015, 111-114; W. Swain, 'The changing nature of the doctrine of consideration, 1750-1850', 26 Journal of Legal History (2006), 55; D.J. Ibbetson, A Historical Introduction to the Law of Obligations, Oxford, 1999, 204.

${ }^{10}$ (1782) 1 Cowper 289, at 294; 98 E.R. 1091.

11 W.S. Holdsworth, 'Blackstone's Treatment of Equity', 43 Harvard Law Review (1929), 1, 20-21.

12 lbid., 20. 
the work of reformation, sick of the delays, the caprice, the prejudices, the ignorance, the malice, the fickleness, the suspicions, the ingratitude of popular assemblies, should seek with his sole hand to expunge the effusions of traditionary imbecility, and write down in their room the dictates of pure and native Justice-Ah! let him but reflect that ... amendment from the Judgment seat is confusion, that partial amendment bought at the expence of universal certainty is but $\left.\right|^{\wedge \wedge \wedge} \mid,{ }^{13}$ that partial good thus purchased is universal evil. ${ }^{14}$

Yet there is no evidence to suggest that Bentham had Mansfield and the introduction of an equitable doctrine of consideration into the common law in view here. Nor is it likely that Bentham would have spoken of a man whom he greatly admired at this time-which Everett and Holdsworth both acknowledged ${ }^{15}$-as someone who was totally exasperated with popular assemblies. Moreover, Bentham is not known to have referred to Atkins v Hill, nor to the case of Hawkes v Saunders, in any of his works or correspondence.

Holdsworth argued that, despite Bentham's 'admiration' of Mansfield, and despite the manner in which his 'dislike for judge-made law' had 'often led him into error', he became a 'sound critic' when he opposed any reform of the law from the bench. ${ }^{16}$ Bentham indeed suggested that law reform should not be implemented from the 'Judgment seat', and that any attempt to do so would create significant uncertainty. But he was here making a far broader point about how reform could not be achieved piecemeal, and about how it ought to be the

${ }^{13}$ At this point, Bentham left a blank in the manuscript approximately four-fifths of a line in length.

14 'Comment' in Comment/Fragment (CW), 223-224. Bentham Papers in the Library of University College London [hereafter UC]. Roman numerals refer to the boxes in which the papers are placed, Arabic numerals to the leaves within each box. UC xxviii. 150 (Undated).

15 A Comment on the Commentaries, Everett ed., 24; Holdsworth, 'Blackstone's Treatment of Equity', 21. Citing Bowring, i. 247.

${ }^{16}$ Holdsworth, 'Blackstone's Treatment of Equity', 21. 
prerogative of a sovereign legislature instead of a rogue member of the judiciary, however well-intentioned. ${ }^{17}$

Given that Bentham appears to have been completely misinterpreted by both Everett and Holdsworth on this subject, what then were his views concerning equity, and did he oppose its so-called 'fusion' with the common law? In answering these questions, and in filling a notable gap in the scholarship, the present article will proceed in the following manner. First, Bentham's opinions concerning the nature of equity in England and his uniquely radical account of its historical development will be examined. It will be shown that Bentham believed that the distinction between the common law and equity was merely a matter of procedure and that he was fiercely opposed to the existence of the two entangled jurisdictions. Then Bentham's reaction to the significant costs and delays associated with the court of chancery in the early nineteenth-century will be discussed. He placed the blame for the problems in chancery wholly upon Lord Eldon, and he called for an immediate solution to provide relief to equity suitors. Finally, Bentham's proposal to establish a series of equity dispatch courts with a remit to clear the large backlog of cases in chancery will be analysed. While he claimed that these courts would be temporary and experimental, they were part of a far more ambitious plan for the reform of the entire English legal system.

It will be argued that Bentham was in favour of 'fusion', but in a very specific form. In the long term, he envisaged the abolition of the procedural distinction between law and equity, the incorporation of the substantive subject-matters handled by courts of equity into his Civil Code, and the use of formal mechanisms to amend the law and to provide relief under his ideal constitution. In the immediate term, Bentham believed that-through his Dispatch Court plan-he could alleviate the defects of the Court of Chancery while simultaneously demonstrating the desirability of a system of county courts and the propriety of his theory of judicial evidence and procedure. With the exception of his influence over Henry Bickersteth, however, it will be concluded that Bentham's ideas on equity had 3tghele impact on the reform of the Court of Chancery in the decades preceding its dissolution in accordance with the

17 'Comment' in Comment/Fragment (CW), 223-224; UC xxviii. 150 (Undated). 
Supreme Court of Judicature Acts (1873-5). ${ }^{18}$

\section{JEREMY BENTHAM AND THE NATURE AND ORIGINS OF EQUITY IN ENGLAND}

Upon being called to the bar in 1769 , the young Bentham was given the preliminary task of shadowing an equity draughtsman. He was to recount how, having been compelled to enter the legal profession by his father Jeremiah-an attorney who harboured grand ambitions for his son one day to become lord chancellor ${ }^{19}$ — his first task had been to draw up an equity bill, prior to defending it before a master in chancery. ${ }^{20}$ He described the moment when he learned of the regular practice of charging the suitor for three days' attendance before the master, 'though no attendance more than one was ever bestowed'. ${ }^{21}$ When Bentham later revisited this experience in Indications respecting Lord Eldon (1825), ${ }^{22}$ he wrote that it helped to

1836 \& 37. Vict. c. $66 ; 38$ \& 39 Vict. c. 77 . See, in particular, M. Lobban, 'Preparing for Fusion: Reforming the Nineteenth-Century Court of Chancery, Part I', 22 Law and History Review (2004), 389; M. Lobban, 'Preparing for Fusion: Reforming the Nineteenth-Century Court of Chancery, Part II', 22 Law and History Review (2004), 565; P. Polden, 'Mingling the Waters: Personalities, Politics, and the Making of the Supreme Court of Judicature', 61 Cambridge Law Journal (2002), 575.

${ }^{19}$ Bentham said that this was the natural wish of any attorney: Chrestomathia $(C W)$, M.J. Smith \& W.H. Burston eds., Oxford, 1993, 52.

${ }^{20}$ Official Aptitude Maximized, Expense Minimized (CW), P. Schofield ed., Oxford, 1993, 206-207.

21 Ibid., 207. Cited in T.D. Hardy, Memoirs of the Right Honourable Henry Lord Langdale, 2 vols., London, 1852, i. 308.

${ }^{22}$ Indications Respecting Lord Eldon, including History of the Pending Judges'-SalaryRaising Measure, by Jeremy Bentham Esq., Bencher of Lincoln's Inn, London, 1825. The critical edition is contained in Official Aptitude Maximized, Expense Minimized (CW), 203-289, which is the text used throughout. 
convince him of the 'exquisitely cemented ... union of sinister interests' in the equity courts of England. ${ }^{23}$ This was a conviction that never left him.

Despite his lifelong interest in the subject, Bentham did not attempt to devise his own definition of the term 'equity' and he believed that to give a definition of it 'in terminis' was essentially impossible. ${ }^{24} \mathrm{He}$ argued that, in its original import, equity was more or less synonymous with the word 'equality', but that this meaning had been long forgotten. ${ }^{25}$ The term equity, asserted Bentham, was a terminological 'abracadabra', ${ }^{26}$ which—like 'right reason', 'fitness of things', or 'natural justice' ${ }^{27}$ —could express approbation but nothing more ${ }^{28}$ As a legal principle, Bentham admitted his own ignorance on the subject, ${ }^{29}$ but said that he found comfort in the fact that even Blackstone did not seem to know what equity was. ${ }^{30}$ In order better to understand the term equity, Bentham said that one must prefix the phrase 'court of' to the term and then look at what it is that a court of equity appeared to do. ${ }^{31}$ Simply to attempt to delineate the functions of an equity court by hazarding a definition of the term, he added, was as useful as explaining the business of the star chamber 'by the

${ }^{23}$ Official Aptitude Maximized, Expense Minimized (CW), 207.

${ }^{24}$ UC Ixxxi. 164-165 (28 April and 14 May 1829).

${ }^{25}$ Bowring, vii. 295n.

${ }^{26}$ Ibid., 291, 302n.

${ }^{27}$ Bowring, vi. 240.

${ }^{28}$ Bowring, i. 327.

29 'Comment' in Comment/Fragment (CW), 326-327.

30 Ibid., 116, 326, 395. See William Blackstone, Commentaries on the Laws of England: A Facsimile of the First Edition of 1765-69, 4 vols., Chicago, 1979, i. 61-62, 91-92. See also Holdsworth, 'Blackstone's Treatment of Equity', 1.

${ }^{31}$ Bowring, vii. 291. Bentham appears to have anticipated Maitland here. See F.W. Maitland, Equity: A Course of Lectures, Cambridge, 1936, 1. 
definition of a star', or of the French 'cour de la table de marbre by the definition of marble'. ${ }^{32}$

In his radical history of English law, Bentham noted that the existence of separate jurisdictions of law and equity was an arrangement altogether 'peculiar to English jurisprudence', which he believed to have been founded neither upon 'nature' nor upon any 'rational cause' whatsoever. ${ }^{33}$ As the development of equity was not a logical necessity in Bentham's eyes, the existence of two separate systems must have had an historical explanation. The explanation he gave was that, so great was the 'stupidity and disregard to the ends of justice' on the part of English judges, a supplemental system of equity developed in order to prevent the common law from producing incongruities and from leaving grievous wrongs remediless. ${ }^{34} \mathrm{He}$ argued further that, in an 'age of darkness', courts of equity arose in order to counteract the sheer 'rapacity' of the 'silly' common law judges who refused 'to do what was absolutely necessary' to administer justice. ${ }^{35}$

According to Bentham, equity only developed because of the 'scantiness of the original scheme of English judicature', which was so defective that it was 'necessary to call in the Roman law. ${ }^{36}$ In the remote past, he noted, what literacy there was had been concentrated in the hands of the ecclesiastics, and 'the king's right-hand man, his virtual first minister', called the lord chancellor, 'was of that profession' ${ }^{37}$ As lord chancellors were clergymen until the time of Sir Thomas More, they necessarily possessed a knowledge of the laws of Rome, upon which they drew in order to fill up the gaps of the laws of England. ${ }^{38}$ It was from this source,

${ }^{32}$ Bowring, vii. 291n., 301.

${ }^{33}$ UC clxviii. 200 (2 Jan. 1808). See also UC xlix. 67 (24 July 1805); Bowring, ii. 87; Bowring, vii. 302.

34 UC clxviii. 200 (2 Jan. 1808).

${ }^{35}$ UC xlix. 62 (18 July 1805).

${ }^{36}$ UC clxviii. 200 (2 Jan. 1808). See also Bowring, vii. 297.

${ }^{37}$ Bowring, vii. 294, 296.

${ }^{38}$ Ibid., 297. See Holdsworth, HEL, i. 410; G.W. Keeton \& L.A. Sheridan, Equity, 3rd edn., London, 1987, 33. 
according to Bentham, that the lord chancellor selected the word 'æquitas' for his motto, which he employed wherever 'money was to be got' by uttering it, both for himself and for his king. ${ }^{39}$

The reason there was no clear line of 'demarcation' between law and equity in the English legal system, Bentham thought, was that the whole arrangement was determined by one big historical 'scramble'. He traced the problem back to the Norman conquest, arguing that, before that time, the 'geographical principle of division' and a system of local courts had been 'nearly' completely established. After the Norman invasion, 'this natural simplicity' was in 'an evil hour ... violated by a wretched attempt at logical demarcation'. ${ }^{40} \mathrm{He}$ described how suits were thereafter subdivided into pleas of the crown, common pleas, and exchequer cases. 'Attached all this while' to the king was his lord chancellor, who was not obliged to hear such suits himself but sold 'permissions to apply for justice' in other courts in the form of writs. ${ }^{41}$ As the individual responsible for issuing writs, the lord chancellor was the person best placed to know where the law did not reach and what remedies remained unavailable. Eventually, it made sense, in Bentham's opinion, to place the chancellor in charge of his own tribunal in the form of the court of chancery, in which he could adjudicate in accordance with the dictates of his conscience.

'In the beginning', in Bentham's account of the early chancery, the lord chancellor-'to whom a commission had been given to judge secundum æquum et bonum'—sat singly, heard every individual in person, weighed all the available evidence, and then came to a decision. ${ }^{42}$ In other words, he adhered to what Bentham called the 'natural' mode, as opposed to the 'technical' mode, of judicial evidence and procedure. ${ }^{43}$ Problems began to arise as soon as the lord chancellor's business started to expand beyond a manageable level. Initially, he remained reluctant to admit of 'a co-ordinate, a rival in office, a sharer in [his] dignity, power,

${ }^{39}$ Bowring, vii. 294-295.

${ }^{40}$ Bowring, vii. 296. See below, n. 78.

${ }^{41}$ lbid.

${ }^{42}$ Bowring, vi. 422; UC Ixxxi. 109 (25 March 1829).

${ }^{43}$ See W. Twining, Theories of Evidence: Bentham \& Wigmore, London, 1985, 47-52. 
and emoluments', but came to accept the need for some assistance. ${ }^{44}$ Something that accelerated this change, said Bentham, was the increasingly widespread use of writing and of parchment. ${ }^{45}$ Originally the lord chancellor employed various clerks for basic 'mechanical' tasks, such as handling these written materials, and their 'number soon rose to twelve'. Shortly afterwards, he claimed that more clerks were necessary, at which time another tier was employed and thereafter the original clerks became known as masters. ${ }^{46}$ 'When [these] clerks became masters, the clerk of the rolls became Master of the Rolls', who was so-called because he would roll up the sheets of parchment into 'spirals'. The lord chancellor soon decided that such administrative duties were beneath him and that judicial 'decision was a more pleasant operation than inquiry', after which the collection of evidence, increasingly in written form, was delegated to other people. He thereafter continued to increase the number of functionaries under his authority and to redirect the duties of his court into 'still lower and lower channels'. In so doing, the lord chancellor created ever more offices that were filled with individuals who all took money from suitors like a 'gang of pickpockets'. ${ }^{47}$ It was thus avarice on the part of the lord chancellor and his functionaries, thought Bentham, that determined the shape of the English system of equity. He described that system as 'a rib of Law ... in some dark age plucked from her side, when sleeping, by the hands not so much of God' as a succession of 'enterprizing' lord chancellors and their numerous subordinates. ${ }^{48}$

Despite having been 'imported' haphazardly from Roman law and implanted into the English legal system by the lord chancellor, ${ }^{49}$ and despite having been formed by the selfinterest of the chancellor and his subordinates, Bentham conceded that the development of

\footnotetext{
${ }^{44}$ Bowring, vi. 422.

45 Ibid., 423.

${ }^{46}$ Ibid., 422-423.

47 Ibid., 423; UC cxiv. 273 (12 May 1829).

48 'Comment' in Comment/Fragment (CW), 395.

${ }^{49}$ Bowring, vii. 303.
} 
equity was at first greatly beneficial. ${ }^{50}$ This was because there was so much that the common law courts, for one reason or another, could not or would not do. Bentham thought that common law judges were stricken with 'stupidity' precisely because they refused adequately to deal with certain matters. Had they heard the cases they refused to hear, they could have easily 'done ... more good', while at the same time making themselves a great deal more money. Bentham even went as far as to suggest that, had the early common law courts rejected the precise forms and strict rules that characterized the 'technical' mode of judicial evidence and procedure, then equity would have been 'prevented from ever coming into existence'. ${ }^{5}$

One crucial power that common law courts lacked that made equity courts necessary, according to Bentham, was the ability to compel specific performance. If a man had agreed to sell an estate to another individual, a common law court could not order the transfer of the property itself if the contract remained unfulfilled. Instead, it could only 'punish him' for 'not having done it', or award the injured party a sum of money. The refusal of common law courts to compel specific performance, in addition to their over-reliance on jury trial, he thought, resulted in their 'incapacity' to 'discharge' the numerous functions upon which the 'continuance of society' depended. His reasoning was that, without the ability to oblige a man to do his legal duty, 'coupled with [an] incapacity of doing anything that could not be done in twenty-four hours' or less owing to the restraints of jury trial, certain substantive subjectmatters could not be dealt with by common law courts. ${ }^{52}$

First, according to Bentham, common law courts could not deal with matters concerning trusts for the reason that trusts required 'continued superintendence' whereas common law courts had long vacations between term times. Second, they were unable to handle the most complex cases owing to the fact that they had 'no tolerable means' of settling a cause which had 'a thousand items' in it. Third, they were unable to handle cases involving more than two parties because they simply 'knew not what to do' with such matters. Fourth,

\footnotetext{
50 lbid., 290.

${ }^{51}$ lbid., 292.

52 Ibid., 293.
} 
they could not intervene to prevent waste. Once a house had been razed, for example, a common law court 'could punish a man for having pulled it down', but it could not prevent him from doing so in the first place. Fifth, common law courts could not deal with cases in which 'a complex mass of property called for distribution' in accordance with a last will and testament, for the same reason that they could not handle other complex suits. Finally, and relatedly, if an executor promised to pay the legacy left by his testator, but instead chose to keep the money, they simply 'knew not what to do with him'. ${ }^{53}$ In order to compensate for the shortfalls of courts of law, courts of equity exercised what Bentham referred to as their 'original' jurisdiction, concerning things uniquely within their remit. The 'original' jurisdiction of equity courts was necessary because of the many flaws of the common law, but their 'controuling' jurisdiction, by which common law proceedings were stopped by injunction, merely led to suits harmfully 'bandying ... from pillar to post' ${ }^{54}$

Nonetheless, Bentham held that it was insufficient to explain equity simply by listing the substantive subject-matters handled in equity courts. ${ }^{55}$ Rather, he understood the key feature of courts of equity to be of a procedural and not of a substantive nature, going so far as to declare that it was 'in the mode of procedure pursued, and in nothing else' that the difference between common law and equity should be sought. ${ }^{56}$ The outstanding procedural feature of equity courts, by which they could be characterized, was that the suits heard within them were initiated by bill. ${ }^{57}$ Bentham believed that bills in equity were unnecessarily prolix ${ }^{58}$

53 lbid., 293-294.

54 Ibid., 298, 300.

55 UC xciv. 300v (29 Sept. 1829).

56 Bowring, vi. 482.

${ }^{57}$ Bowring, vii. 292.

${ }^{58}$ Bowring, vi. 498. See also P. Polden, 'The Court of Chancery, 1820-1875', in W. Cornish et al eds., The Oxford History of the Laws of England, Oxford, 2010, xi. 661 [hereafter OHEL]. Citing John Mitford, A Treatise on the Pleadings in Suits in the Court of Chancery by English Bill, 2nd edn., London, 1787, 47. 
and packed with falsehood, ${ }^{59}$ and were designed to obtain information in a number of months that could have been obtained in 'an hour or less by vivâ voce examination' (his preferred method of judicial truth-finding) ${ }^{60}$ His other criticisms of equity procedure were that oral evidence was only taken in the form of interrogatories or depositions in the 'secret mode' 61 and that 'epistolary' or written evidence always predominated. ${ }^{62}$

Bentham was resolutely opposed to what he saw as the existence of two separate and entangled jurisdictions, where it was so difficult to distinguish where one ended and the other began. ${ }^{63}$ His main 'grievance' was the existence of two sorts of law and 'two sets of judges pulling in different ways' whilst 'tearing to pieces the property' of suitors. ${ }^{64} \mathrm{He}$ thought it profoundly absurd that the common law and equity both purported to pursue justice but often handled quite different subject-matters and went about it using highly 'discordant' methods of procedure. ${ }^{65}$ In Rationale of Judicial Evidence (1827), ${ }^{66}$ Bentham proclaimed that 'No man regarding the subject with a view to the ends of justice and the welfare of society, can seriously believe that the existence of two repugnant masses of substantive law-that the

${ }^{59}$ Bowring, vi. 482.

${ }^{60}$ UC Ixxiv. 342 (22 May 1804).

${ }^{61}$ Bowring, vi. 491; UC clxviii. 201 (11 Jan. 1808).

${ }^{62}$ UC clxviii. 201 (11 Jan. 1808). For a contemporary overview of the evidence and procedure of English equity courts, see R.N. Gresley, A Treatise on the Law of Evidence in the Courts of Equity, London, 1836.

${ }^{63}$ UC xlix. 69 (17 July 1805). See also Bowring, vi. 83; Bowring, vii. 290, 295.

${ }^{64}$ Bowring, vii. 302.

${ }^{65}$ lbid., 300.

${ }^{66}$ Rationale of Judicial Evidence, Specially Applied to English Practice. From the Manuscripts of Jeremy Bentham, Esq. Bencher of Lincoln's Inn, 5 vols., London, 1827 (Bowring, vi. 191-585; Bowring, vii. 1-600). 
existence of two repugnant masses of adjective law ... - is really conducive to those ends' ${ }^{67}$ While Bentham maintained that the distinction between common law and equity was 'purely arbitrary and imaginary' and largely based upon a difference of procedure, ${ }^{68}$ he said there had once been a very real 'war' between the two systems which produced 'monstrous results'. ${ }^{69}$ He suggested that the long period of time during which common law and equity stood with 'daggers drawn' against one another quickly subsided when men of the law realized that there was greater profit to be made if they 'shook hands and embraced'. Prior to the 'confederacy' of the two types of court, all of their suitors were 'crushed by their collision', but thereafter their sufferings only intensified. As both systems served only the interests of the men involved in their operation, it was agreed among them that, once the common law had 'picked the bones of a cause', equity could then come in and 'suck ... the marrow'. ${ }^{70}$

After that unspecified point in time when a truce was made between law and equity, argued Bentham, 'instead of righting and scolding' each other, courts of common law and courts of equity devised 'ways and means' for increasing their respective profits. ${ }^{71} \mathrm{He}$ referred to law and equity as 'depredators' which hunted 'in couples', before vividly describing how 'One of the pair runs violently against a man, and knocks him into the kennel; the other, with sympathetic eagerness, runs up to his assistance, drives off the assailant, helps up the sufferer, and picks his pockets. The ruffian thief is common law; the hypocrite thief is equity. ${ }^{72}$

An important piece of proof cited by Bentham of the complicity of law and equity was a line in A Treatise on the Pleadings in Suits in the Court of Chancery (1780) by John FreemanMitford. In order to prevent a 'multiplicity of suits', Mitford recommended that a plaintiff should bring a suit before a common law court prior to filing a bill in equity so as first to establish his

${ }^{67}$ Bowring, vii. 291.

${ }^{68}$ Bowring, ii. 87.

${ }^{69}$ Bowring, vii. 303-305.

${ }^{70}$ Ibid., 300. See also UC Ixxxv. 165 (7 April 1827).

${ }^{71}$ Bowring, vii. 303.

72 Ibid., 298. 
rights. ${ }^{73}$ On the contrary, according to Bentham, the requirement that a suitor would have to bring a suit at law and a suit at equity would not only lead to a 'multiplicity' of cases, but would significantly increase the levels of expense, vexation, and delay experienced by each party. Bentham alleged that even as former lord chancellor of Ireland and as one of the most notable 'institutional writers' on the subject, Mitford was completely unable to delineate 'the boundary line' of equity itself with any degree of 'regularity'. ${ }^{74}$

To give a brief example of what Bentham saw as the mutual rapacity of the 'two everjarring masters' of law and equity, ${ }^{75}$ he pointed out that courts of law and courts of equity could take cognizance of matters of fraud. He posed the question of whether or not it should be 'endurable' that two vastly divergent systems should be able to hear the same sorts of suit and decide upon them in vastly different ways. Where, he enquired, was the legislator,

while two sets of judges, both being, or professing to be, under his command, were thus busying themselves in opposite ways about fraud-one employed in setting it up, the other in overthrowing, or making believe to overthrow it? Answer:-Fast asleep ... foxed by the essence of nonsense, poured down his throat on both sides. $^{76}$

The legislator had been 'fast asleep', Bentham thought, just as he had been all the while that law and equity had been intertwined. ${ }^{77}$ Bentham also addressed the arrangement whereby certain courts, like exchequer or chancery, had both a common law and an equity jurisdiction. He referred to these courts as having 'two metaphysical sides': 'metaphysical' in this context being Bentham's term for a manner of dividing the business of courts by any method other

\footnotetext{
${ }^{73}$ Mitford, $A$ Treatise on the Pleadings in Suits in the Court of Chancery by English Bill, 128.

${ }^{74}$ Bowring, vii. 296-297.

${ }^{75}$ Ibid., 300.

${ }^{76}$ Ibid., 301, 305.

${ }^{77}$ Ibid., 305.
} 
than 'geographical' demarcation. ${ }^{78} \mathrm{He}$ fundamentally disagreed with a system whereby 'the same bench' would have its 'equity days' and its 'common-law days'. Such a jurisdictional arrangement, thought Bentham-like any other system of law where there prevailed two divergent types of substantive law and two vastly different modes of procedure-was nothing more than 'elaborated confusion, and licensed pillage'. ${ }^{79}$

Overall, Bentham took great pleasure in pointing out that a 'higher' and 'purer' system of equity supplanted and corrected the common law ${ }^{80}$ and at least attempted to rectify some of its deficiencies, even if they were secretly working in concert. ${ }^{81} \mathrm{He}$ referred to the famous phrase of Sir Edward Coke that the common law was the 'perfection of reason', ${ }^{82}$ before remarking that the growth of equity as a 'new and smoother' kind of law was a very strange supplement to something perfectly reasonable. ${ }^{83}$ Far from being the perfection of reason, the common law sat on a 'lower shelf', while 'above it, on a higher shelf', sat equity, with its 'superior degree of strength' ${ }^{84}$ Nevertheless, Bentham argued that any 'conflict' between the two types of court was merely superficial, in that a common law court was rarely 'dissatisfied' whenever it had already 'had its fees'. ${ }^{85}$ The main problem was that, by being 'stronger', a remedy at equity was sold to suitors at a far greater price than a remedy at common law, and

${ }^{78}$ Ibid., 301. See also First Principles Preparatory to Constitutional Code (CW), P. Schofield ed., Oxford, 1989, 37; UC clxviii. 200 (2 Jan. 1808).

${ }^{79}$ Bowring, vii. 301.

${ }^{80}$ Bowring, v. 305.

${ }^{81}$ Bowring, vii. 290.

${ }^{82}$ Co. Litt. 97b.

${ }^{83}$ Bowring, vi. 307.

${ }^{84}$ Ibid., 134. See also Official Aptitude Maximized, Expense Minimized (CW), 334 \& n. where Bentham, parodying Edward Burtenshaw Sugden's pamphlet attacking John Williams, equated law and equity to oil and vinegar.

${ }^{85}$ Bowring, vii. 292. 
was coupled with the likelihood of enormous delays. ${ }^{86} \mathrm{He}$ asserted that, while equity courts consistently alleviated the defects of the common law and made up for the imbecility of its judges, they did so at the cost of 'keeping the parties for months or years in hot water' and at enormous expense. ${ }^{87}$

In Bentham's preferred model, a uniform system of 'natural procedure' would be adopted and thus equity bills, depositions, interrogatories, affidavits, and so on, would have no place. By abolishing equity procedure, he would, by his own definition, have abolished equity along with it. A comprehensive system of statute law-with its own mechanisms for making amendments and for providing relief incorporated into it-would then replace the common law. ${ }^{88}$ In this codified system of legislation would be placed all the necessary subject-matters formerly handled by courts of equity, such as trusts. ${ }^{89}$ Yet Bentham recognized that these reforms were not likely to be achieved imminently and that he ought to devise an interim solution. As will be shown below, in his equity dispatch court proposals, Bentham advocated the simplest possible method of instigating court proceedings by petition and a summary form of procedure in which everyone would arrive at court with all their deeds in hand and witnesses in tow and be cross-examined vivâ voce. It was because of the dire state of the court of chancery, the blame for which he placed upon Lord Eldon, that he considered such a measure to be a matter of urgency.

${ }^{86}$ UC clxviii. 202 (2 Jan. 1808).

${ }^{87}$ Bowring, vii. 291.

${ }^{88}$ For detailed discussion, see Schofield, Utility and Democracy, 310-312; F. Rosen, Jeremy Bentham and Representative Democracy: A Study of the Constitutional Code, Oxford, 1983, 160-163; Postema, Bentham and the Common Law Tradition, 436-439; M. Lobban, The Common Law and English Jurisprudence: 1760-1850, Oxford, 1990, 152-153; Dinwiddy, Bentham: Selected Writings of John Dinwiddy, 158-162.

${ }^{89}$ For the inclusion of trusts within Bentham's civil code, for example, see UC Ixviii. 268-285 (3-8 June 1827) and the corresponding marginal summary sheets at UC Ixiv. 40-41 (22 June 1827). 


\section{JEREMY BENTHAM, THE COURT OF CHANCERY, AND THE 'LORD OF DOUBTS'}

Bentham argued that all English subjects felt 'sorely aggrieved by the delay, expense, and vexation' that were caused by the desperate conditions of the court of chancery. ${ }^{90} \mathrm{He}$ regarded it as a place where 'lying and extortion' had been in 'constant practice' for a significant length of time. ${ }^{91}$ In chancery, the delays faced by litigants were interminable, with Bentham claiming that fourteen or fifteen years was "no very immoderate duration for a Chancery Suit'. ${ }^{92}$ Bentham referred to a pamphlet entitled $A$ Review of the Delays and Abuses Occasioned by the ... Present Practice of the Court of Chancery with Practical Hints as to the Remedy (1825), which stated that 'most suits' took up to twenty years to come to a close. ${ }^{93}$ Bentham also alleged that it was 'in direct contravention' of Magna Carta that 'justice in [His] Majesty's Equity Courts' had 'at all times ... been delayed to all, without exception' ${ }^{94}$

Central to the expense of a suit in chancery, according to Bentham, were the many 'lucrative offices' that were worth substantial sums of money to their occupants. Each tier of

90 Bowring, iii. 303.

${ }^{91}$ UC cxiv. 269 (11 May 1829).

92 The Correspondence of Jeremy Bentham (CW), A. Taylor Milne ed., Oxford, 1981, v. 304.

${ }^{93}$ A Review of the Delays and Abuses Occasioned by the Constitution and the Present Practice of the Court of Chancery with Practical Hints as to the Remedy, London, 1825, British Library C.T. 80.(6), 54. In citing this figure and the preceding, Bentham appears to have overlooked the distinction between the judicial and the administrative functions of the court and the sheer number and variety of parties in certain cases.

${ }^{94}$ Bowring, iii. 303, 328. 
office-holder, from the lord chancellor downwards, added to the fees attached to each suit. ${ }^{95}$ Among the highest paid of these functionaries was the master of the rolls, ${ }^{96}$ who was described by Bentham as a 'creature' with a persistent 'finger in the pie'. ${ }^{97}$ One of the ways in which the master and his clerks manufactured delay and expense, said Bentham, who had witnessed it at first hand, was through their systematic non-attendance.${ }^{98}$ Citing a pamphlet entitled A Letter to Samuel Compton Cox, Esq. one of the Masters of the Court of Chancery (1824), he said that masters rarely made their arrival before 11 am and would set off for home before 3 pm. ${ }^{99}$ Another pamphlet, entitled A Letter to William Courtenay, Esq. One of our Commissioners for Inquiring into the Practice established in the Court of Chancery (1824) by William Vizard, gave their usual time of departure as $2 \mathrm{pm} .{ }^{100}$ In his own marked copy of Vizard's pamphlet, Bentham commented on this particular disclosure with the simple words: 'Masters' attendances-sinister interest'. ${ }^{101}$

Another troubling issue, for Bentham, was the practice of charging suitors for multiple ${ }^{95}$ Bowring, iv. 434n.

${ }^{96}$ Bowing, ix. 313.

${ }^{97}$ Bowring, ii. 49.

${ }^{98}$ Official Aptitude Maximized, Expense Minimized (CW), 209. See above, n. 23.

99 Ibid. Citing $A$ Letter to Samuel Compton Cox, Esq. one of the Masters of the Court of Chancery, respecting the practice of that Court, with suggestions for its alteration. By a Barrister, London, 1824, 15.

100 Official Aptitude Maximized, Expense Minimized (CW), 209-210. Citing W. Vizard, A Letter to William Courtenay, Esq. one of the Commissioners for inquiring into the practice established in the Court of Chancery, London, 1824, 32.

${ }^{101}$ Vizard, A Letter to William Courtenay, British Library C.T. 80.(6), 32. Vizard gave evidence before the chancery commission in July 1824 and in June and November 1825. See Chancery Commission. Copy of the Report made to His Majesty by the Commissioners Appointed to Inquire into the Practice of Chancery, London, 1826, Appendix (A.), 29-56, 340, 459-463 [hereafter Chancery Commission Report]. 
copies of written documents which they did not need or sometimes never received. As Birrell notes, for the suitor to refuse to accept unnecessary copies and the fees that went with them was to incur the 'enmity' of the chancery officials. ${ }^{102}$ Bentham considered the phenomenon of being charged for superfluous documents from chancery as a clear indication of the 'rapacity' and corruption in the court. ${ }^{103}$ Bentham cited Casamajor v Strode (1819), in which the total charges for written copies of particulars of sale reached $£ 700 .{ }^{104} \mathrm{He}$ referred to this as a 'portentously scandalous instance' where 'Lord Eldon's eyes [were] forced open' ${ }^{105}$ to the extent that he was forced to pass the general order of 24 March 1814, which limited the cost of copies to sixpence per side and capped the number of copies that could be issued. ${ }^{106}$ At this point in his own marked copy of $A$ Letter to Samuel Compton Cox, Esq., Bentham wrote succinctly: 'Masters. Swindlers'. ${ }^{107}$

Bentham argued that it was impossible for potential suitors to calculate how much a suit in chancery would cost them or how long it would take. ${ }^{108} \mathrm{He}$ alluded to an attempt by Lord Thurlow to draw up tables of all the costs in chancery during his time as lord chancellor. However, after Thurlow resigned the great seal in 1782, the tables disappeared and never

${ }^{102}$ A. Birrell, A Century of Law Reform: Twelve Lectures on the Changes in the Law of England During the Nineteenth Century ... Michaelmas Term 1900 and Hilary Term 1901, London, 1900, 192.

103 Official Aptitude Maximized, Expense Minimized (CW), 209, 211, 214-215.

104 (1819) 1 Wilson Chancery 428; 37 E.R. 182. See A Letter to Samuel Compton Cox, Esq. one of the Masters of the Court of Chancery, 11.

105 Official Aptitude Maximized, Expense Minimized (CW), 211.

${ }^{106}$ See John Beames, The General Orders of the High Court of Chancery: From the Year 1600 to the Present Period, London, 1815, 483-484.

107 A Letter to Samuel Compton Cox, Esq. one of the Masters of the Court of Chancery, British Library C.T. 80.(6), 9.

108 UC cxiv. 268-269 (11 May 1829). 
rematerialized. ${ }^{109}$ Bentham also discussed Morgan v Lord Clarendon, a case included in the report of the chancery commission of 1824 , which he interpreted as 'a highly instructive exemplification of the length and expense of a Chancery Suit'. This case, which had been in progress for sixteen years, had already cost the plaintiff nearly $£ 4000$ in fees even before the appointment of counsel. ${ }^{110}$ Examples like this, said Bentham, were sufficient proof of the complete 'depredation under the name of Equity', which served only to benefit the 'Chancellor, Masters, and the rest of the swarm of learned locusts' in chancery. ${ }^{111}$

In a manuscript intended for Scotch Reform written on 8 March 1808, Bentham described how 'a mass of property to a vast but unknown amount [had] been accumulated' in total by the court of chancery. ${ }^{112}$ By the time he wrote to the duke of Wellington on 12 December 1829 — entreating the then prime minister to become a 'hero of Peace' and a 'child of Justice' through the medium of law reform—he could cite a concrete figure. ${ }^{113}$ With reference to a return ordered by parliament on 10 February 1829, he told Wellington of suitors' effects held in chancery to the astronomical value of $£ 39,216,326 .{ }^{114}$ This was further

${ }^{109}$ Official Aptitude Maximized, Expense Minimized (CW), 229. Citing James Lowe, Observations on fees in Courts of Justice, London, 1822, 19-21. Lowe gave evidence before the chancery commission in August 1824. Chancery Commission Report, Appendix (A.), 160-172, 217-223.

${ }^{110}$ UC cxiv. 271 (12 May 1829); Chancery Commission Report, Appendix (A.), 298; Appendix (C.), 587-604. See also Holdsworth, HEL, ix. 365.

${ }^{111}$ UC cxiv. 271 (12 May 1829).

112 UC Ixxxii. 115 (8 March 1808).

${ }^{113}$ Bowring, xi. 11.

114 Ibid. See Court of Chancery. Returns of the amount of the effects of suitors,-of rehearings and appeals before the Lord Chancellor and Vice-Chancellor ... on the first day of Hilary term, London, 1829. Cited in William Adam, The State of the Court of Chancery; the Causes which retard the Proceedings and Termination of Suits, and a 
evidence, for Bentham, that chancery was a 'great Vortex' that swallowed up 'all the fortunes in the Kingdom'. ${ }^{115}$

The man who Bentham blamed for the wretched state of chancery was Lord Eldon, who, excluding a brief interval during the Ministry of All the Talents, held the office of lord chancellor for almost twenty-five years. ${ }^{116}$ Under Eldon, Bentham said, equity became cemented as 'an instrument of fraud and extortion', ${ }^{117}$ resulting in 'the ruin of so many thousands of families'. ${ }^{118}$ Admittedly, there had long been a large backlog of suits pending before the court prior to his tenure $\mathrm{H}^{119}$ and significant, unnecessary costs to suitors once their causes were finally heard. ${ }^{120}$ However, in Bentham's view, all the problems in chancery had

suggestion of means to diminish the delays and expenses of that court, London, 1829, $313 n$.

115 'Comment' in Comment/Fragment (CW), 326.

${ }^{116}$ See John Campbell, The Lives of the Lord Chancellors and the Keepers of the Great Seal of England, from the Earliest of Times Till the Reign of King George IV, 7 vols., 2nd edn., London, 1846-7, vii. 471.

117 Official Aptitude Maximized, Expense Minimized (CW), 206.

118 Bowring, xi. 10; Bowring, ii. 74. The economic, social, and psychological damage wrought by chancery was, of course, to be denounced by Charles Dickens in Bleak House (1851-53). See Blake, Pleasures of Benthamism, 8-10.

${ }^{119}$ Even if, under Eldon, the arrears in chancery increased and became increasingly politicized. See M. Lobban, 'Preparing for Fusion Part I', 400-409; D.M. Kerly, An Historical Sketch of the Equitable Jurisdiction of the Court of Chancery: Being the Yorke Prize Essay of the University of Cambridge, Cambridge, 1890, 183.

${ }^{120}$ Bickersteth told the chancery commission that he knew of several cases where a whole estate 'proved insufficient to pay the costs'. See Chancery Commission Report, Appendix (A.), 217. Cited in H. Horwitz \& P. Polden, 'Continuity or Change in the Court of Chancery in the Seventeenth and Eighteenth Centuries?', 35 Journal of 
been amplified to the 'highest possible pitch' during Eldon's time in office. ${ }^{121}$ Furthermore, his drawn-out style of adjudication, in addition to his staunch opposition to reform of any kind, made Eldon a regular subject of Bentham's attention.

In a short memorandum delivered to Bentham at his home in Queen's Square Place, Westminster on 13 June 1825, James Mill—recounting the words of their mutual friend Sir Samuel Romilly from a few months before his death-adequately summarized Bentham's view of Eldon. ${ }^{122}$ Romilly reportedly said that chancery was the 'disgrace of civilized society', and, most importantly, that 'not only was Lord Eldon himself the cause of many of the abuses', but that 'the remedy of the greater part of them [lay] in his hands'. ${ }^{123}$ On two notable occasions, Bentham also referred to the incident on 3 November 1818, when, upon entering the court and seeing Romilly's empty seat the day after his suicide, Eldon wept and the court had to be adjourned. ${ }^{124}$ These tears, according to Bentham, were merely those of a 'crocodile' by whom, with the help of the other 'tygers and jackalls' in chancery, the people and their estates were so frequently 'devoured'. ${ }^{125}$

One of the significant contributing factors to the state of affairs in chancery, in Bentham's view, was the hugely powerful nature of the lord chancellorship. Bentham said that

British Studies (1996), 24, 24-25. On Bentham and Bickersteth, see below, nn. 231255.

${ }^{121}$ Official Aptitude Maximized, Expense Minimized (CW), 205.

122 Ibid., 259n.; UC xix. 32 (13 June 1825).

${ }^{123}$ Official Aptitude Maximized, Expense Minimized (CW), 259n.

${ }^{124}$ Colonies, Commerce, and Constitutional Law: Rid Yourselves of Ultramaria and Other Writings on Spain and Spanish America (CW), P. Schofield ed., Oxford, 1995, 109 \& n.; Official Aptitude Maximized, Expense Minimized (CW), 276. See also Horace Twiss, The Public and Private Life of Lord Chancellor Eldon, with selections from his correspondence, 3 vols., 2nd edn., London, 1844, ii. 324.

125 The Correspondence of Jeremy Bentham (CW), L. O'Sullivan \& C. Fuller eds., Oxford, 2006, xii. 399. 
whoever held the office stood as a 'monster' in comparison with which 'the chimera of the poets was an ordinary beast, their triple-bodied Geryon an ordinary man'. ${ }^{126} \mathrm{He}$ attempted to list all the powers at the disposal of the lord chancellor-including 'keeper of the great seal; a transcendental, multifarious, and indefinable office', ${ }^{127}$ member of the cabinet, and adviser to the king-before giving up and saying that his full range of powers could not be enumerated. ${ }^{128}$ Bentham said that, with so many tasks to perform, it was unsurprising that Eldon did not have as much time as was necessary to devote to chancery. ${ }^{129}$ In the Administration of Justice Act (1813), provision was made for the installation of a vicechancellor to ease the lord chancellor's busy schedule. ${ }^{130}$ For Bentham, the appointment of a vice-chancellor to share the workload in chancery was completely unsatisfactory. In Constitutional Code, he argued that the new vice-chancellorship was an ill-contrived strategy made to appear 'to atone' for Eldon's 'inaptitude' and for the insufficient amount of time he bestowed on 'the business of judicature'. All that this measure did was increase the delay, ${ }^{126}$ Bowring, vi. 381. Geryon was a giant slain by Hercules. See Virgil, Aeneid, vI. 285 \& VIII. 200.

127 This description of the keeper of the great seal is mistakenly used to describe the lord chancellorship in R.P. Meagher, W.M.C. Gummow, \& J.R.F. Lehane, Equity: Doctrines and Remedies, 3rd edn., Sydney, 1992, 3. Parkes, who is cited, did not make this mistake. See Joseph Parkes, A History of the Court of Chancery; with Practical Remarks on the Recent Commission, Report, and Evidence, and On the Means of Improving the Administration of Justice in the English Courts of Equity, London, 1828, 437.

${ }^{128}$ Bowring, vi. 381; Bowring, ix. 519. For the duties of the lord chancellor from a contemporary source, see 'Reforms in Chancery', 1 Law Magazine (1828-9), 32, 33.

${ }^{129}$ Bowring, vi. 381. See also Bowring, v. 18.

${ }^{130} 53$ Geo. III. c. 24. See J. McGee ed., Snell's Equity, 33rd edn., London, 2005, 8; Polden, 'The Court of Chancery, 1820-1875', 646, 648; G.W. Keeton, An Introduction to Equity, 6th edn., London, 1965, 20. 
vexation, and expense experienced by suitors, by creating 'an additional grade or say stage of judicature' through which the decisions of the vice-chancellor could be appealed to the lord chancellor. ${ }^{131}$ As with the chancery commission, which was chaired by Eldon himself to investigate his own court, Bentham questioned the effectiveness of any measure of reform led by the most problematic figure in an establishment: ${ }^{132}$ '[B]etween the Master of the Rolls and himself did this creator and preserver of all Judicial abuse, cram in a Vice-Chancellor; lest the number of the snares and plagues rained down upon the people on pretence of administering justice should be incomplete'. ${ }^{133}$ A crucial issue which could not be alleviated by the introduction of a vice-chancellor was Eldon's indecisiveness and time-consuming method of adjudication when in court. ${ }^{134}$ As described by Lord Campbell, Eldon had a habit of speaking 'very luminously' for hours on the merits of a case and giving 'a strong opinion in favour' of one side or the other, before declaring that he would take the papers home in order to pore over them in private. ${ }^{135}$ Polden describes how Eldon's lack of conviction and his long deliberations would constantly encourage rehearings and appeals. ${ }^{136}$ It is this tendency to which Bentham referred when humorously branding him as 'Lord Endless'137 and 'the Lord of ${ }^{131}$ Bowring, ix. 520. On this point, Bentham agreed with M.A. Taylor, a passionate advocate for chancery reform in parliament. However, they do not appear to have corresponded.

132 Official Aptitude Maximized, Expense Minimized (CW), 237; Constitutional Code (CW), F. Rosen \& J.H. Burns eds., Oxford, 1983, 110 \& n. See also Lobban, 'Preparing for Fusion Part l', 409.

133 Bowring, ix. 520.

${ }^{134}$ See UC Ixxxi. 167 (May 1829).

${ }^{135}$ Campbell, Lives of the Lord Chancellors, vii. 625. See also Twiss, The Public and Private Life of Lord Chancellor Eldon, iii. 338.

136 Polden, 'The Court of Chancery, 1820-1875', 673, 647.

137 The Correspondence of Jeremy Bentham (CW), S. Conway ed., Oxford, 1989, ix. 230; Church of Englandism and its Catechism Examined (CW), J.E. Crimmins \& C. 
Doubts'. ${ }^{138}$ All who gained by Eldon's hesitation, wrote Bentham-namely anyone who was entitled to a portion of the suitor's fees-were left 'in extacy' by the lord chancellor's idiosyncratic irresolution. ${ }^{139}$

In an unpublished section of Bentham's equity dispatch court plans, as discussed below, there is a remarkable comparison between Eldon's qualifications and style of arbitration and that of Lords Erskine and Lyndhurst. In anticipation of objections that the new tribunals would undermine a great tradition of education in English law and equity, he aimed to show that people with less experience of equity proceedings proved to be more effective judges in chancery. Bentham said that, for the task of deciding equity cases, some degree of 'appropriate cognitional aptitude' was required, but, provocatively, he denied that the skills necessary exceeded the 'common sense' and 'common honesty' possessed by any lay individual. ${ }^{140} \mathrm{He}$ did add, however, that a common lawyer with no equity experience, like Erskine, was also found perfectly suitable. ${ }^{141}$

When was acquaintance with ... [or] experience in equity court practice ever looked for-when the want of it ever felt, in the case of an Equity Judge? Think of Lord Erskine! Never had he set his foot in an Equity Court, till he was made sole singlyseated Judge of ... these oppressive edifices. ${ }^{142}$

Fuller eds., Oxford, 2011, 500n. Cited in Polden, 'The Court of Chancery, 1820-1875', 647. See also R. Melikan, John Scott, Lord Eldon, 1751-1838: The Duty of Loyalty, Cambridge, 1999, 313. Notably, this is one of only two references to Bentham in Melikan's work.

${ }^{138}$ Bowring, x. 77.

139 UC Ixxxi. 167 (May 1829).

140 UC cxiv. 281 (18 May 1829).

${ }^{141}$ Ibid. See also UC Ixxxi. 154 (6 May 1829). This was also a criticism levelled against Lord Brougham. See John Campbell, Lives of Lord Lyndhurst and Lord Brougham, Lord Chancellors and Keepers of the Great Seal, London, 1869, 373.

142 UC cxiv. 281 (18 May 1829). 
Whether it was learning in the common law branch or in the equity branch of the English legal system, said Bentham, never had a judge less of it than Lord Erskine. ${ }^{143}$ Erskine instead possessed 'commonplace eloquence' and basic common sense. ${ }^{144}$ The difference between Erskine and Eldon on this point, according to Bentham, could not have been more striking: In Lord Erskine, you had Equity learning at its [minimum]: ${ }^{145}$ in Lord Eldon you had it, and have it still (much good may it do you!), at its maximum: in no intellectual warehouse was the stock of misery-distributing and mutually-conflicting absurdities and inconsistencies so richly abundant.

In practice, the implication of this was very simple: wherever 'Lord Erskine decided; Lord Eldon doubted'. ${ }^{146}$ But why, asked Bentham, if learning and experience were so highly valued, would someone like Erskine have been appointed lord chancellor in the first place, given that one of the most important of his duties would be to act as the principal judge of the court of chancery? For the same reason that Lyndhurst was also made lord chancellor, despite having never 'set foot in an Equity Court', ${ }^{147}$ namely patronage and corruption. ${ }^{148}$ Erskine's fatal flaw, thought Bentham, was his 'blind attachment to Jury trial'. If he could have been 'weaned' from it, he speculated that Erskine would perhaps have made a good judge in one of his dispatch ${ }^{143}$ See J. Hostettler, Thomas Erskine and Trial by Jury, Hampshire, 1996, 177-178; Campbell, Lives of the Lord Chancellors, vi. 552-554. Citing Samuel Romilly, Memoirs of the Life of Sir Samuel Romilly, Written by Himself; with a selection from His Correspondence, 3 vols., London, 1840, ii. 128-129.

144 UC cxiv. 281 (18 May 1829).

145 MS orig. 'maximum' contradicts the evident flow of the sentence.

146 UC cxiv. 281 (18 May 1829).

${ }^{147}$ Bentham was incorrect here, in that Lord Lyndhurst had been made master of the rolls in 1826. Prior to this, he had no experience in chancery. See D. Lee, Lord Lyndhurst: the Flexible Tory, Colorado, 1994, 54, 107; Campbell, Lives of Lord Lyndhurst and Lord Brougham, 42-44.

148 UC cxiv. 282 (18 May 1829); UC cxiv. 289 (30 May 1829). 
courts. $^{149}$

It is also worth noting here one logical implication of Bentham's stance on the qualifications of someone deciding equity suits. As a legal education was not a prerequisite for an equity judge, and as experience in the workings of chancery was not necessary either, it was a natural conclusion that 'no regard at all' ought to be paid to previous decisions when deciding a cause. ${ }^{150}$ Bentham explained that it was of 'comparatively recent instance' that lord chancellors would take cognizance of the rulings of their predecessors when determining the outcome of a case. In effect, said Bentham, the first individual to do so had been struck by 'a fit of delirium' and had 'betrayed the cause of equity' by applying precedent to an equity suit. ${ }^{151} \mathrm{He}$ also added that equity had of late become 'as settled and as general' as the common law itself, leading to much 'ambiguity' and 'difficulty' in attempting to unpick their entangled jurisdictions. ${ }^{152}$ As Eldon is said to have performed much of the final formalization of equity ${ }^{153}$ and to have instigated a much greater reliance upon precedent in chancery, ${ }^{154}$ it is clear that, unlike Erskine, Eldon certainly would not have made a suitable appointment in one of Bentham's Dispatch Courts.

IV. THE DISPATCH COURT PLAN: 'EQUITY SUITORS...WOULD YOU OBTAIN

${ }^{149}$ UC cxiv. 283 (18 May 1829).

${ }^{150}$ Bowring, v. 563-565. See W.H.D. Winder, 'Precedent in Equity', 57 Law Quarterly Review (1941), 245; Kerly, An Historical Sketch of the Equitable Jurisdiction of the Court of Chancery, 185.

${ }^{151}$ Bowring, vi. 40. Emphasis supplied. See also Bowring, v. 564-565.

152 'Comment' in Comment/Fragment (CW), 324.

${ }^{153}$ D.R. Klinck, 'Lord Eldon on Equity', 20 Journal of Legal History (1999), 51.

154 See Kerly, An Historical Sketch of the Equitable Jurisdiction of the Court of Chancery, 1; D. Browne ed. Ashburner's Principles of Equity, 2nd edn., London, 1933, 35-37; R. Edwards \& N. Stockwell, Trusts and Equity, 8th edn., Essex, 2007, 3. 
RELIEF FROM TORMENT?'

As Postema observes, Bentham first suggested the idea of a system of equity dispatch courts in Justice and Codification Petitions (1829), before turning his full attention to the scheme in the spring of $1829 .{ }^{155}$ The unique remit of the courts would have been very simple. They were conceived in order to clear the arrears of chancery through the use of the speediest possible form of summary procedure. In print, Bentham's dispatch court plans are contained in the Proposal, first published in 1830, ${ }^{156}$ and the 'Bill', a version of which was collated and published posthumously in the Bowring edition of The Works of Jeremy Bentham (183843). ${ }^{157}$ The crucial difference between the Proposal and the 'Bill' is that the former was intended to attract signatories for a petition to the king, while the latter was intended to be put before the house of commons. On 31 January 1831, having published the Proposal and written eight sections of the 'Bill', Bentham conceded that the Proposal had been a failure. ${ }^{158}$ Yet he added that he was no less determined to pursue equity reform and continued to work on the 'Bill' until late June.

The anonymous preface to the 'Bill' describes how it was one of the last works in which Bentham was engaged and how the manuscripts remained in an incomplete state at his

${ }^{155}$ Postema, Bentham and the Common Law Tradition, 414. Citing Bowring, v. 437545. See Bowring, iii. 304.

156 Equity Dispatch Court Proposal: Containing a Plan for the Speedy and Unexpensive Termination of the Suits Now Depending in Equity Courts. With the form of a Petition, and Some Account of a Proposed Bill for that Purpose, London, 1830 (Bowring, iii. 295-317).

157 'Equity Dispatch Court Bill; Being a Bill for the Institution of an Experimental Judicatory Under the Name of the Court of Dispatch ... Now First Published from the MSS. of Jeremy Bentham' (Bowring, iii. 319-430).

158 UC Ixxxvi. 255 (31 Jan. 1831). Bowring, iii. 390-391n. 
death. ${ }^{159}$ It also states that the 'Bill' ought to be read in conjunction with Bentham's procedure code material. ${ }^{160}$ There is little evidence to suggest that Bentham intended these two works to be linked in any substantial way, however, and for one fundamental reason. In two lettersone to Sir Francis Burdett on 12 June 1825 and the other to Sir Robert Peel on 14 January 1827-Bentham declared that, in the procedure code on which he had been working since $1823,{ }^{161}$ 'the nonsensical distinction between Law and Equity [had] no place'162 and had been 'compleatly discarded' from his vision of law reform. ${ }^{163}$ Nonetheless, as Postema notes, Bentham did anticipate that his dispatch courts would be an excellent arena in which initially to test and 'to demonstrate' some of his theories of judicial evidence and procedure. ${ }^{164}$

In a draft advertisement for the Proposal, Bentham addressed the 'honest class' of equity suitors: 165 'Would you obtain relief from torment by the unexpensive substitution of days or minutes to the years of delay, with correspondent expence, to which you stand doomed by Equity? Enquire at 2 Wellington Street for Dispatch Court Proposal, price $2^{\text {s }}$. Secrecy is necessary to you as if it were for a crime'. The reason for the clandestine nature of this address, he explained, was the very reasonable fear of the "wrath produced by the conjoined interest of Judges, Barristers, and Solicitors' that was likely to be directed at suitors for seeking reform. ${ }^{166}$ Outside this group of opponents, who were most likely to try to thwart the ${ }^{159}$ Bowring, iii. 320. A likely candidate for the editorship of the 'Bill' is Arthur Moore. Moore's handwriting is found throughout Box 86 , noting the dates on which various sheets were copied and specifying which were excluded from the text.

160 Ibid., Bowring, ii. 5-188.

${ }^{161}$ See Constitutional Code (CW), i. pp. xxxv-xxxvi.

162 Correspondence (CW), xii. 126.

163 lbid., 273.

${ }^{164}$ See Postema, Bentham and the Common Law Tradition, 420. Citing Bowring, iii. 322

165 UC cxiv. 291 (15 May 1829).

166 UC cxiv. 292 (15 Dec. 1829). 
implementation of the scheme because they benefitted so greatly from the existing state of chancery, Bentham argued there would be little need for persuasion. There certainly would be no need to convince individuals who had suits pending before the court of the desirability of the measure, because their 'feelings' afforded 'sufficient proof' of their 'affliction'. ${ }^{167}$ Even among the English people at large, the fact that 'the delay and expence' in chancery called 'irresistibly for diminution' was widely 'acknowledged without a dissenting voice'. ${ }^{168}$

The form of Bentham's proposed solution was as follows. A statute would first establish a dispatch court committee composed of dispatch court judges, ${ }^{169}$ who would be appointed for a two-year period unless removed for breach of duty. ${ }^{170}$ Each commissioner would be required to make an inaugural declaration in which he would renounce all forms of 'delinquency' into which his 'situation exposes him to fall'. ${ }^{171}$ This declaration, said Bentham, would serve as a 'memento' to the members of the public to remain 'upon the watch over' the commissioners' conduct. ${ }^{172}$ The best people for the job of commissioners, he thought, would be justices of the peace who had experience of sitting in general sessions. ${ }^{173}$ After due notice

167 Bowring, iii. 299.

168 UC cxiv. 264 (13 May 1829).

169 UC Ixxxi. 148 (5 May 1829).

${ }^{170}$ UC Ixxxi. 149 (29 March 1829).

${ }^{171}$ UC Ixxxi. 132 (9 May 1829). Bentham also proposed inaugural declarations for all legislators and judges. See Constitutional Code (CW), i. 133-146; Bowring, ix. 532535.

172 UC Ixxxi. 132 (9 May 1829).

${ }^{173}$ UC Ixxxi. 155 (6 May 1829). Bentham saw general sessions of justices of the peace as the ideal model of the 'natural' mode of procedure. See UC Ixxxi. 127 (8 May 1829); Bowring, vi. 422; Bowring, vii. 300. See also Postema, Bentham and the Common Law Tradition, 352-353. 
given in the London Gazette, ${ }^{174}$ the committee would then produce a report on the suits in pendency' before chancery and determine which would be suitable for hearing. ${ }^{175}$ Those types of cases categorically excluded from Bentham's plans would consist of those where the necessary evidence could not be rendered 'forthcoming' within the time proposed ${ }^{176}$ and those cases which would require 'the collection and distribution of the matter of a pecuniary fund' of an indefinite amount. ${ }^{177}$ As for the pending equity suits that would have been eligible for the experiment, everything would depend upon the consent of the suitors. If both the plaintiffs and defendants 'joined in praying' for the 'substitution' of a hearing before a dispatch court instead of a hearing before an existing tribunal, then their case could be brought. ${ }^{178}$ The method of initiating a suit in chancery by bill would be completely replaced by a form of handwritten petition to a dispatch court by the plaintiffs, giving all the necessary details of the suit and the nature of the relief sought. ${ }^{179}$

Each dispatch court would be erected with an initial three-year lifespan, ${ }^{180}$ and in each would be placed a single judge ${ }^{181}$ with a handful of subordinates. ${ }^{182}$ In order to ensure that no

${ }^{174}$ UC Ixxxi. 261 (20 Jan. 1831).

175 UC Ixxxi. 114 (20 April 1829).

176 Bowring, iii. 313.

177 UC Ixxxi. 154 (6 May 1829). While Bentham did not explicitly say as much, it may be assumed that long-term administrative suits and cases involving numerous parties_including infants, invalids, and the deceased-would also have been exempt. 178 UC Ixxxi. 130 (8 May 1829).

${ }^{179}$ UC cxiv. 266 (11 May 1829). For the information required from each petitioner, see Bowring, iii. 315-316.

180 Bowring, iii. 300.

${ }^{181}$ UC Ixxxi. 131 (9 May 1829). For the list of the judge's powers over the dispatch court, see Bowring iii. 345-376. 
'premium for delay' would be granted to officials, ${ }^{183}$ Bentham recommended the complete substitution of fixed annual salaries in place of court fees for all dispatch court judges and their functionaries. ${ }^{184}$ These fixed salaries would be paid by the treasury in order to distribute the costs of each suit over the country as a whole, and thus make equity accessible to everyone. An exception to this would arise in the case of proven 'malâ fide' suitors, who would pay all their own costs. ${ }^{185}$ By far the most important characteristic of Bentham's scheme, however, would be the substitution of 'hours, or even minutes' for the 'years' ordinarily spent waiting for a case in equity to be decided. ${ }^{186} \mathrm{He}$ thought that he could achieve this through the adoption of a summary form of procedure in each dispatch court, as distinct from the 'technical' mode that existed in chancery. ${ }^{187}$

Bentham argued that English courts of equity had adopted 'the most oppressive of all' the regular systems of judicial evidence and procedure, and that it was this that caused so much delay, vexation, and expense. ${ }^{188} \mathrm{He}$ suggested that the summary mode, in contrast, would be extremely simple and almost immediate in effect. Instead of the time-consuming process of bill and answer to instigate proceedings, instead of a reliance upon written evidence, and instead of depositions away from court, Bentham envisioned that all the parties would turn up at a dispatch court on a specified date, along with all their documentation and

182 Including: a 'Judge Depute' to preside over the court while the 'Judge Principal' was absent (Bowring, iii. 343-345); an 'Auxiliary Judge', roughly equivalent to the master of the rolls (ibid., 395-406); an 'Eleemosynary Advocate' to safeguard poor suitors (ibid., 342); 'Prehensors' and 'Messengers' to oversee the transfer of people and of documents (ibid., 376-381); and a registrar (ibid., 341-342).

183 UC Ixxxi. 107 (23 March 1829); Bowring, iii. 309.

${ }^{184}$ UC Ixxxvi. 214 (21 June 1829).

185 UC Ixxxi. 107 (23 March 1829).

186 UC Ixxxvi. 407 (17 May 1829).

${ }^{187}$ Bowring, iii. 299. See also Schofield, Utility and Democracy, 324-325.

188 Bowring, iii. 304. 
all their witnesses. ${ }^{189} \mathrm{He}$ imagined that there would be no need for lengthy pre-trial proceedings to establish the type of relief sought by the plaintiffs, to determine the position of the defendants, or to uncover all the available evidence. Instead, everyone would simply arrive at court and proceedings would immediately begin. He envisaged that the plaintiffs and defendants would 'voluntarily ... bring all deeds and other ready-written instruments in [their] custody or power' with them, as well as 'all such witnesses' as they had need of, in order simultaneously to be examined on the day of the hearing. ${ }^{190}$

As Polden argues, William Hutton's court of requests came closest to the 'Benthamite ideal' in this regard. ${ }^{191}$ Bentham himself said as much in 'London Petition for Judicial Reform and against Eldon' (1826), in which he intended directly to refer parliament to Hutton's endeavours in Birmingham. ${ }^{192}$ In the Proposal, he asserted that the full practicality of the natural mode of procedure was demonstrated by courts of requests. ${ }^{193}$ In $1807-8$, he also used the impressive statistics achieved by Hutton's tribunal in order to extrapolate the number of suitors who, nationwide, were being denied justice. ${ }^{194} \mathrm{He}$ believed that Hutton had

${ }^{189}$ Ibid., 329. See also UC Ixxxi. 148 (5 May 1829); UC Ixxxvi. 214 (21 June 1829).

190 UC Ixxxi. 129 (8 May 1829).

${ }^{191}$ P. Polden, 'Local Courts: Courts of Requests', OHLE, xi. 848-857, 853. In 1794, Bentham wrote that courts of requests were 'creeping over the Kingdom' under 'the auspices of necessity': UC xx. 85 (c. Sept. 1794).

192 UC Ixxxi. 3 (8 July 1826). William Hutton, Courts of Requests: their Nature, Utility, and Powers Described, with a Variety of Cases, Determined in that of Birmingham, Birmingham, 1787. In 1807, Hutton offered to Bentham his 'book, pen, and head': Correspondence (CW), vii. 406-408. For several questions in a copyist's hand, and responses in that of Hutton, see UC xciv. 77 (27 Jan. 1807).

${ }^{193}$ Bowring, iii. 299, 304. See also Bowring, v. 7.

${ }^{194}$ See UC xciii. 20, 30-31, 33, 37 (Feb. 1807); UC xciv. 76, 78 (24-25 Jan. 1808). 
accomplished such great efficiency, at such little expense, ${ }^{195}$ owing to a lack of formal rules, ${ }^{196}$ to the common-sense adjudication of a layperson, ${ }^{197}$ and to the examination of all parties and of all evidence in open court. ${ }^{198}$

So convinced was Bentham that dispatch court judges would be able to achieve 'rectitude of decision'-by having everyone and every piece of documentation placed before them at each trial—that he stipulated no provision for appellate review. ${ }^{199} \mathrm{He}$ argued that, 'By appeal, whatsoever benefit was expected from the institution would be done away: [because] Appeal from a summarily proceeding Court to a regularly ... proceeding Court would be a selfrepugnant arrangement. ${ }^{200}$ The ultimate problem, he foresaw, was that of having the decisions of a dispatch court, with its summary mode of procedure, being appealed back to chancery, or even to a common law court, which still retained the regular mode of procedure. Very 'sad would be your case', predicted Bentham, 'if, after having been taken out of the hands of the Equity Court Judges' and placed into the hands of a dispatch court judge, you were 'sent back to those same tardy and rapacious hands' as before. ${ }^{201}$ The only possible exception to the 195 See UC xciii. 27 (9 Feb. 1807). Hutton, Courts of Requests, 30, 40-45. Although, in 1796, Bentham noted that a brief interval in an Industry House could have been cheaper for some debtors. See Writings on the Poor Laws: Volume I (CW), M. Quinn ed., Oxford, 2001, 97.

196 See, for instance, UC Ixxxvi. 314 (10 Feb. 1831).

197 UC Ixxxiv. 299 (2 Feb. 1831); Bowring, iii. 400.

198 UC xciv. 342v (3 Feb. 1807); Hutton, Courts of Requests, 29-36. See also H.W. Arthurs, "Without the Law": Courts of Local and Special Jurisdiction in Nineteenth Century England', in A. Kiralfy, M. Slatter, \& R. Virgoe, eds., Custom, Courts and Counsel: Selected Papers of the 6th British Legal History Conference, London, 1985, $130-149,136-137$.

199 Bowring, iii. 299, 306.

200 UC Ixxxi. 132 (9 May 1829).

${ }^{201}$ Bowring, iii. 308. See also UC Ixxxi. 154 (6 May 1829). 
denial of appeal, said Bentham, would be in the case of 'misdemeanour' on the part of a 'Commissioner of Dispatch'. ${ }^{202}$ This aside, the 'judge's ultimate decrees' would have to be made 'definitive'. 203

As Schofield notes, Bentham asserted that the ultimate standard by which suits would be adjudicated in each dispatch court would be the 'disappointment-prevention principle'. ${ }^{204}$ He thought that this principle was completely self-explanatory, since everyone had felt a pain of disappointment at some time or another, and he recommended that it supplant all existing rules and practices in courts of equity. ${ }^{205}$ He referred to all contemporary doctrines of equity as 'scandalously inconsistent' with the minimization of disappointment and he proclaimed that they should be abandoned. ${ }^{206}$ Instead, 'a much better chance for the prevention of disappointment' and therefore of pain would be afforded 'by aiming at that object immediately', rather than 'through so unconducive, and in every respect unapt a medium', as those established rules. ${ }^{207}$ Only in the context of wills did he provide two supplementary principles of adjudication which were to apply in his dispatch courts. These were the "benefit-maximizing principle' and the 'lot-employing principle', concerning which he gave virtually no explanation. 202 UC Ixxxi. 150 (29 May 1829).

203 Bowring, iii. 308.

${ }^{204}$ Schofield, Utility and Democracy, 326. See also UC Ixxxi. 125 (1 May 1829); Bowring, iii. 388.

205 UC Ixxxi. 100 (23 March 1829); Postema, Bentham and the Common Law Tradition, 417. See also UC Ixxxi. 124 (30 April 1829), where Bentham noted that this principle had been given a 'pretty full exposition' in 6 Westminster Review (1826), 446, 502.

${ }^{206}$ Bowring, iii. 389.

207 Ibid., 312. See Postema, Bentham and the Common Law Tradition, 415-416. Notably, dispatch courts would not adhere to the previous decisions of other dispatch courts, although the application of the 'disappointment-prevention principle' might coincide in some instances. 
If none of these three principles could resolve the case, it should, he suggested rather vaguely, be settled in a manner that would best 'benefit ... the whole community'. ${ }^{208}$ In each dispatch court, said Bentham, these principles would completely replace all of the 'rules' of equity by which suitors were originally subjected to utter 'plunderage'. ${ }^{209}$

Regarding the equity dispatch court project as a whole, Bentham argued that the level of 'disturbance' to English law would be non-existent and that things would 'go on as if nothing had happened'. ${ }^{210}$ However, he often intimated that the scheme would not be temporary but would be an opportunity to initiate far more comprehensive law reform. ${ }^{211}$ For example, he spoke of the 'Annihilation' or 'Extinction' of chancery altogether, despite his assurance that everything would stay largely unchanged. Nonetheless, Bentham was careful to provide a means of compensation to the professionals who would be likely to suffer significant pain from the loss of office, fees, and reputation under the dispatch court plan. ${ }^{212} \mathrm{He}$ predicted that, provided that any reparations cost the taxpayer as little as possible, ${ }^{213}$ the 'great relief' that would be afforded to the numerous and long-afflicted equity suitors would far outweigh the possible pains experienced by displaced chancery officials. ${ }^{214}$

Alongside the provision of compensation, Bentham made an attempt to counter the objection that 'the whole existing system of Equity [would] be subverted' by his scheme and that security of property would therefore be jeopardized. Would property be at risk by the erection of his equity dispatch courts, he asked? 'No such thing'. Those affected would be solely those 'who are parties to the suits to which the new course of procedure applies itself'.

\footnotetext{
${ }^{208}$ Bowring, iii. 390.

209 lbid., 312.

210 UC Ixxxi. 133 (9 May 1829).

211 See Postema, Bentham and the Common Law Tradition, 420-421.

${ }^{212}$ UC Ixxxi. 134 (16 May 1829); UC Ixxxvi. 211 (30 June 1829). See also, in general,
} Official Aptitude Maximized, Expense Minimized (CW), 342-366.

${ }^{213}$ UC Ixxxvi. 210 (30 June 1829).

${ }^{214}$ UC Ixxxi. 144 (5 May 1829). 
In all other cases in existing courts, 'the business will be performed according to such rules as are at present in existence: rules of substantive law including rules of procedure'. ${ }^{215}$ Nor, he said, would existing precedents undergo any change. ${ }^{216}$ Elsewhere, Bentham exclaimed:

Foundations of property shaken! will of course be among the cries raised against the proposal of this same Equity Dispatch Court ... as if that could be shaken which has no existence. Foundations shaken! instead of shaken, say rather established. Resting on the at-present-existing grimgribber, the pretended rule of action rests upon a quicksand with volcanoes under it. ${ }^{217}$

His view was that it made little sense to speak of security of property when legal and equitable remedies were so elusive and so extremely costly to suitors. Nevertheless, it is difficult to imagine how the replacement of all the rules of equity with the loosely-defined 'disappointment-prevention principle', and the complete alteration of the system of procedure through which chancery suits were heard, could have taken place without considerable disruption. The radicalism at the core of Bentham's dispatch court plan truly manifested itself, however, when he professed that upon the 'will of the supremely ruling few' depended all possibility of reform 'in this as in every other shape'. ${ }^{218}$ Once the 'film of authority-begotten prejudice' had been removed 'from the eyes of a too long and too deeply injured people' whose suits were pending before chancery, ${ }^{219}$ Bentham predicted that the temporary reform of English equity would 'lead to—-turn men's minds to-[and] give ... encouragement to-reform in every other shape'. ${ }^{220}$ This language would have appeared particularly threatening to those whom Bentham needed to persuade to adopt or to support his project.

Finally, it is also worth addressing Bentham's suggestion that, in order for the equity

215 UC Ixxxvi. 412 (11 May 1829).

${ }^{216}$ UC Ixxxi. 133 (9 May 1829).

${ }^{217}$ Bowring, iii. 390n.

218 UC cxiv. 251 (28 April 1829).

${ }^{219}$ UC cxiv. 252 (28 April 1829).

${ }^{220}$ UC cxiv. 251 (28 April 1829). Emphasis supplied. 
dispatch court system to be successful, the establishment of county courts would be necessary. As discussed above, he argued that an adequate network of local courts had been in place in Saxon times, but that they had been 'gradually extinguished' following the Norman conquest. ${ }^{221}$ While Bentham conceded that such a task could only be 'a work of long time and large expence', ${ }^{222}$ he believed that justice would be far better achieved by avoiding burdensome journeys to the metropolis. He considered that, in order to lessen this burden, it would be preferable for local dispatch courts to be erected so that cases could be heard without any party 'passing the night elsewhere than at his own home'. ${ }^{223}$ Despite his preference for a network of local courts across England, however, Bentham was severely sceptical about Lord Brougham's Bill for Establishing Courts of Local Jurisdiction (1830). ${ }^{224} \mathrm{He}$ thought that Brougham was no utilitarian and no reformer, and that Brougham's bill had departed dramatically from his own plans. ${ }^{225}$ Needless to say, however, it is difficult to see how Bentham's vision of the 'revival' of the 'all-comprehensive system of local judicatories' from 'the days of our Saxon ancestors' could ever have been reconciled with a temporary initiative. ${ }^{226}$ This part of his dispatch court scheme may thus be interpreted as a means by which Bentham intended to implement the system of local courts which he had set out in Constitutional Code..$^{227}$

221 Bowring, iii. 329, 304; Bowring, v. 448. See also Sokol, Bentham, Law and Marriage, 70.

222 UC Ixxxi. 127 (8 May 1829).

${ }^{223}$ UC Ixxxvi. 214 (21 June 1829).

${ }^{224}$ See 'Mr. Brougham and Local Judicatories', 13 Westminster Review (1830), 420. His annotated copy of Brougham's bill is at UC iv. 10-24. See also P. Polden, $A$ History of the County Court, 1846-1971, Cambridge, 1999, 20-21.

${ }^{224}$ Correspondence (CW), xii. 126.

225 'Mr. Brougham and Local Judicatories', 420-421. See also Bowring, v. 553.

${ }^{226}$ Bowring, iii. 304.

${ }^{227}$ See Bowring, ix. 454-540. 


\section{CONCLUSION}

Bentham was highly critical of the entire system of equity in England, and in particular of the court of chancery and its leading villain Lord Eldon. Contrary to the opinions of Everett and Holdsworth, Bentham never directly addressed Lord Mansfield's ideas concerning the introduction of the equitable principle of consideration into the common law in any of the works or unpublished manuscripts discussed above, nor was he particularly concerned with doctrine. Rather, Bentham advocated a quite different form of 'fusion' in which the procedural distinction between law and equity would be discarded, the substantive subject-matters of equity would be transferred into his civil code, and formal mechanisms to amend the law and to provide relief would be incorporated into his ideal constitution. In the interim, had Bentham's dispatch court invention been successful, the 'disappointment-prevention principle' would have applied and nothing would have been imported from law or equity. The form which either of these scenarios would have taken would have been vastly different from Mansfield's approach of incrementally introducing into the common law equitable doctrines through individual judicial actions. $^{228}$

In the overall historical narrative surrounding this aspect of English legal history, however, it must be conceded that Bentham's role is rather uncertain. In a number of studies which trace the reform of equity and the court of chancery up to the Supreme Court of Judicature Acts, Bentham is portrayed as a minor figure, when he is mentioned at all. ${ }^{229}$ One exception is in the work of Kerly, who argued that, in the area of evidence and procedure, Bentham's proposal for the admission of testimony from all interested parties was 'strictly adhered to' in chancery until the middle of the nineteenth century. ${ }^{230}$ In attempting to assess Bentham's legacy, and in particular when attempting to trace his impact upon subsequent reforms, it is helpful to look at the individuals with whom he corresponded and upon whom he

228 'Comment' in Comment/Fragment (CW), 223-224.

${ }^{229}$ See above, n. 18.

${ }^{230}$ Kerly, An Historical Sketch of the Equitable Jurisdiction of the Court of Chancery, 261. 
exerted an influence. The best example in this context is the Benthamite barrister Henry Bickersteth. $^{231}$

Bickersteth, who later became master of the rolls, gave evidence before the chancery commission in August $1824 .{ }^{232}$ Bentham was impatient to receive a copy of his evidence in transcript, ${ }^{233}$ and Bickersteth delivered it to him on 4 January 1825 , more than a year before the publication of the official report. ${ }^{234}$ As Parkes notes, Bickersteth 'attack[ed] the evils' that the commissioners seemed 'afraid to handle' in his evidence to the chancery commission and his first response to his examiner shows 'the feeling which characterises his evidence' as a whole. ${ }^{235}$ Part of his opening testimony could have been spoken by Bentham himself: 'I conceive that unnecessary delay, vexation and expense may be ascribed to the established process and practice of the court; to the established system of pleading; and to the mode of obtaining evidence'. ${ }^{236}$ Bickersteth also told the chancery commission that the process of bill and answer needed reform, ${ }^{237}$ that the best method of receiving evidence would be vivâ voce cross-examination, ${ }^{238}$ and that Eldon had too little time to sit at court and was often plagued by 'doubts' when present. ${ }^{239}$ Perhaps the most significant statement made by Bickersteth, however, was that, until the law was

defined with as much clearness and certainty as the variety and fluctuation of

${ }^{231}$ Polden, 'The Court of Chancery, 1820-1875', 654.

${ }^{232}$ Chancery Commission Report, Appendix (A.), 145-151, 173-183, 209-217.

233 See Correspondence (CW), xii. 124.

${ }^{234}$ Ibid., 90, 95. Bentham's gratitude for receiving Bickersteth's evidence is expressed in a letter printed in Hardy, Memoirs of the Right Honourable Lord Langdale, i. 357358.

${ }^{235}$ Parkes, A History of the Court of Chancery, 552.

${ }^{236}$ Chancery Commission Report, Appendix (A.), 145. Emphasis supplied.

237 lbid., 153.

238 Ibid., 181, 183, 209.

239 Ibid., 212, 216. 
human affairs will permit, no regulations of the mere practice of courts can be effectual. ... [A] general revision and statement of the whole system of law is required ... before it can be satisfactorily determined [how] the court of Chancery can be most advantageously administered. ${ }^{240}$

This is pure Benthamism, from a man who would go on to 'revise' and 'approve' parts of 'Equity Dispatch Court Bill'. ${ }^{241}$ Bentham thought Bickersteth 'virtuous'242 and a 'most cordial friend to law reform to its utmost extent', but he became concerned when Bickersteth was offered the newly-created chief judgeship in bankruptcy, which he eventually rejected. ${ }^{243}$

When Bickersteth was offered the position of master of the rolls in 1836, after Bentham's death, it was James Mill who persuaded him that he could more effectively promote law reform if he accepted the accompanying peerage, thus making him first baron Langdale. ${ }^{244}$ Although Hardy asserted that Bickersteth was never a 'Radical', only a 'thorough Reformer', ${ }^{245}$ it is clear that his correspondence and meetings with Bentham had had a significant effect upon him. ${ }^{246}$ To give a few examples, during his mastership, Bickersteth sat on a committee created by Lord Cottenham, in which he pledged to 'prevent vexatious delays' and curtail 'unnecessary expense' for equity suitors. ${ }^{247}$ More broadly, Bickersteth argued for a

240 lbid., 216.

${ }^{241}$ Bowring, xi. 39.

${ }^{242}$ Correspondence (CW), ix. 143.

243 Bowring, xi. 39. See Henry Brougham, The Life and Times of Henry Lord Brougham, Written by Himself, 3 vols., Edinburgh and London, 1871, iii. 425.

${ }^{244}$ Hardy, Memoirs of the Right Honourable Henry Lord Langdale, i. 451-453, 459.

245 Ibid., ii. 101. Yet, apparently some of Bickersteth's colleagues did think him rather radical: ibid., i. 468 .

246 Ibid., i. 383.

247 'The New Orders in Chancery', 26 Law Magazine (1841), 260, 264. Cited in Polden, 'The Court of Chancery, 1820-1875', 664 and n. 
system of local courts, ${ }^{248}$ for the simplification of the law, ${ }^{249}$ for reduced vacation times, ${ }^{250}$ and for rules of evidence and procedure that were closely approximate to Bentham's ideas. ${ }^{251}$ Furthermore, Bickersteth told the select committee on fees in courts of law and equity (1848) that the costs of chancery suits fell disproportionately on poorer suitors and that all fees ought to be replaced with fixed salaries at the expense of the taxpayer. ${ }^{252}$ Perhaps owing in no small part to Bentham's influence, Hardy states that Bickersteth remained an 'enemy to the delays and costs of law proceedings' and to the 'denial of justice' until his death in $1851 .{ }^{253}$ In the month before he died, Bickersteth stood before the house of lords and, citing Bentham's $A$ Protest Against Law Taxes (1795), declared 'that the time was come for the full and practical application of the maxims of that learned and ingenious man'. ${ }^{254}$ On the other hand, Hardy notes that Bickersteth consistently viewed his responsibility as master of the rolls as being not to amend the law, but to administer it, and that, like Eldon, he adhered firmly to established precedents in chancery. ${ }^{255}$ Nor did Bickersteth ever appear directly to endorse Bentham's dispatch court programme.

Despite Bickersteth's apparent Benthamism, it remains difficult to determine the extent to which Bentham's ideas had an overall impact upon English equity leading up to its final 248 Hardy, Memoirs of the Right Honourable Henry Lord Langdale, ii. 17, 40, 46. 249 Ibid., ii. 46. ${ }^{250}$ Ibid., ii. 60-62.

${ }^{251}$ Ibid., ii. 78-79. Bentham wrote to Bickersteth on 18 September 1827, urging him to read Rationale of Judicial Evidence. See ibid., i. 372-373.

252 'First Report from the Select Committee on Fees in Courts of Law and Equity', London, 1848, 147-148. See Lobban, 'Preparing for Fusion Part II', 572.

${ }^{253}$ Hardy, Memoirs of the Right Honourable Henry Lord Langdale, ii. 40.

${ }^{254}$ Ibid., ii. 44. House of Lords Debates (1851) cxiv. 1113. See Writings on Political Economy: Volume I (CW), M. Quinn ed., Oxford, 2016, 269-298.

${ }^{255}$ Hardy, Memoirs of the Right Honourable Henry Lord Langdale, ii. 50, 72-74. Citing Bullin v Fletcher(1836) 1 Keen 369, at 379; 48 E.R. 348. 
'fusion' with the common law. One must conclude, says Lobban, that the 'reform of the court was not ideology-driven' and was not motivated by 'Benthamite codification or substantive fusion'. ${ }^{256}$ Nor, he adds, was any 'Benthamic invective' ever 'strong enough' to reform the old court of chancery, or to alter its relationship with the common law itself. ${ }^{257}$ The lack of evidence of any tangible influence on Bentham's part may be attributable to the fact that his ideas were not effectively disseminated. Between June 1830 and December 1831, the Proposal sold a meagre twenty-three copies and was never reviewed. ${ }^{258}$ The 'Bill' remained unpublished until 1839, and, when it did materialize, it appeared in the minuscule print and double-columned typesetting of Bowring's The Works of Jeremy Bentham, where it has since remained.

\section{Acknowledgements}

I would like to express my sincere gratitude to Professor Philip Schofield, Dr lan Williams, Dr Michael Quinn, Dr Miles Layram, and my two anonymous referees, for their highly insightful comments and criticisms regarding this paper. I would like further to thank Professor Schofield and Dr Quinn for their invaluable assistance in deciphering a number of the near-illegible words on several of the Bentham manuscripts cited herein. Any mistakes are mine alone.

\footnotetext{
${ }^{256}$ Lobban, 'Preparing for Fusion Part II', 566.

257 lbid., 599.

${ }^{258}$ See BL Add MS 33,553, fos. 301-2, 309-10. In 1830, William Wellesley claimed that Bentham's 'name' and 'principles' stood 'foremost' in the debate on equity reform, but this was probably an attempt at flattery: see William Wellesley, Illustrations of Chancery Practice, London, 1830. pp. iii-iv. See BL Add MS 33,546, fos. 414-415.
} 


\section{Notes on Contributor}

Chris Riley is a PhD student and Transcription Assistant at the Bentham Project, Faculty of Laws, University College London (UCL). His doctoral thesis, entitled 'Jeremy Bentham and the Utility of History', is funded by the London Arts and Humanities Partnership. 